Peer-reviewed scientific periodical, focusing on legal and economic issues of antitrust and regulation. Creative Commons Attribution-No Derivative Works 3.0 Poland License.

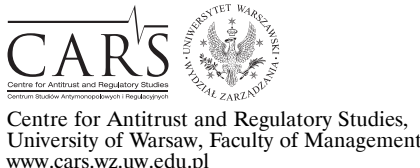
www.cars.wZ.uw.edu.pl

\title{
Passing-on of Overcharges and the Implementation of the Damages Directive in CEE Countries
}

\author{
by \\ Raimundas Moisejevas*
}

\section{CONTENTS}

I. Introduction

II. The concept of passing-on

III. The Damages Directive and passing-on of overcharges

1. Provisions in the Damages Directive related to passing-on of overcharges

2. Causation

3. Impact of the overcharge

4. Member States' regulation on passing-on

IV. Conclusions

\begin{abstract}
The article focuses on the concept of passing-on of overcharges and the peculiarities of its regulation by the Damages Directive. The Damages Directive obliges Member States to ensure that the defendant in an action for damages may invoke the passing-on defence. Moreover, the Directive establishes the new framework and the main principles that govern the application of the passing-on defence. The national case law on passing-on is very insignificant in Central and Eastern European countries and many questions are expected to be raised in the courts of the CEE Member States. While discussing the concept of passing-on in the Damages Directive, a lot of emphasis should be paid to the issue of causation. Causation will definitely be the subject of most of the questions in cases when an indirect purchaser will bring a claim for damages. Causation may be tricky when an indirect purchaser claims it suffered an 'overcharge harm' because of passing-on. In

* Dr. Raimundas Moisejevas - Attorney at law, Arbitrator, ICSID Conciliator and Professor in Business Law Department, Faculty of Law, Mykolas Romeris University, Lithuania, raimundas.moisejevas@vilgerts.com. Article received: 02.08.2017; accepted: 22.08.2017.
\end{abstract}


most cases, the issue of causation will be decided mainly by national courts based on national procedural rules. Depending on the situation, passing-on may be used as a basis for the claim (as a 'sword') or as a defence (as a 'shield'). It could be used as a basis for the claim by an indirect purchaser, in case s/he has suffered any harm because of the illegal actions of a cartelist or a dominant company. At the same time, it could be used as a defence by the infringer against a claim for damages. The article also analyses the specifics of the implementation of the Directive into the national laws of CEE Member States.

\section{Résumé}

Larticle se concentre sur le concept de répercussion du surcoût et sur les particularités de sa réglementation par la Directive Dommages. La Directive Dommages oblige les États membres à veiller à ce que le défendeur, dans une action en dommages, puisse invoquer un moyen de défense invoquant la répercussion du surcoût. En outre, la Directive établit le nouveau cadre et les grands principes régissant l'application de la défense invoquant la répercussion du surcoût. La jurisprudence nationale sur la répercussion du surcoût est très insignifiante dans les pays d'Europe centrale et orientale et de nombreuses questions devraient être soulevées devant les tribunaux des États membres d'Europe centrale et orientale. En discutant du concept de répercussion du surcoût dans la Directive Dommages, il convient de mettre l'accent sur la question du lien de causalité. La causalité fera certainement l'objet de la plupart des questions dans les cas où un acheteur indirect intentera une action en dommages et intérêts. La causalité peut être délicate lorsqu'un acheteur indirect affirme avoir subi «un préjudice du surcoût» en raison de la répercussion du surcoût. Dans la plupart des cas, la question de la causalité sera tranchée principalement par les tribunaux nationaux sur la base des règles de procédure nationales. Selon la situation, la répercussion du surcoût peut servir de base pour prétendre à une indemnisation (comme une «épée») ou en tant que défense (comme un «bouclier»). Il pourrait servir pour prétendre à une indemnisation par un acheteur indirect, au cas où il aurait subi un préjudice en raison des agissements illégaux d'un cartel ou d'une société dominante. Dans le même temps, il pourrait être utilisé comme un moyen de défense par l'auteur d'une infraction contre une action en dommages. Larticle analyse également les spécificités de la mise en œuvre de la Directive dans les législations nationales des Etats membres d'Europe centrale et orientale.

Key words: antitrust damage; consumers; passing-on of overcharges; Lithuania; private enforcement of competition law; antitrust damage claims; Directive on antitrust damages actions; calculation of damages.

JEL: D40; K21; K23; L40; L42; L44 


\section{Introduction}

Directive 2014/104/EU (hereinafter, the Damages Directive) was signed into law on 26 November 2014 and published in the Official Journal of the European Union on 5 December 2014. ${ }^{1}$ The Damages Directive has introduced many new elements aimed to increase the amount of private enforcement in EU Member States. The Damages Directive also coined harmonized rules concerning the passing-on of overcharges, which is quite a new idea for some jurisdictions. All Member States were obliged to implement the Directive till 27 December 2016; however this was not an easy task bearing in mind a big number of new concepts.

It should be noted that many concepts established in the Damages Directive, including the concept of passing-on, might by understood differently in separate Member States. The difficulty of the task of implementing the Damages Directive is especially obvious considering that many EU Member States have failed to implement it by its due date, as it was initially envisaged. Moreover, in Lithuania for example, national officials discussed whether it is enough for the implementation of the Directive to amend the Law on Competition, or whether the Civil Code and the Civil Procedure Code should also be amended. Therefore, the Damage Directive was initially a big challenge for Member States' legislators and the implemented provisions may now become a challenge for national judges and attorneys.

We believe that problems related to passing-on would be best understood in a practical case, when an attorney or a judge faces a legal puzzle. Let's imagine that as attorney you need to advice a shop that specializes in the sale of different cheeses. The Competition Council finds out about a three-year long cartel between farmers who produced milk and that the cartel could have caused an around 15\% price increase of milk. The cheese shop doesn't buy milk directly from the farmers. Farmers sell milk to big dairy manufacturers. After this, your client buys cheese from milk-processing companies. Your client asks you to evaluate his chances for a successful litigation against the cartelists (milk producers). First, you need to identify who has the right to make a claim against the cartelists. Are all entities that could have experienced damage in the production and distribution chain of milk entitled to bring a damages claim? What about milk-processing companies, resellers of milk products or end-consumers? Are they all entitled to bring a damages claim on the same

1 Directive 2014/104/EU of the European Parliament and of the Council of 26.11.2014 on certain rules governing actions for damages under national law for infringements of the competition law provisions of the Member States and of the European Union, OJ L 349, 05.12.2014. 
basis? Second, it is important to evaluate how the damages experienced by the milk-processing companies, resellers of milk products or end-consumers should be assessed. Is there one universal rule or are different rules applicable depending on your position in the distribution chain? Is it important to evaluate the proportion of the cost of milk in the overall production costs of the product? Third, one of the key issues here is causation. Proving causation is always tricky in antitrust damages cases, and especially when we deal with indirect purchasers.

The implementation of the provisions concerning passing-on and indirect purchasers may also help assist end-consumers in the recovery of damages. This is especially important bearing in mind the calculations of the European Commission that cartels in the EU cause every year damages to the victims of more than EUR 10 billion. ${ }^{2}$ The Damages Directive provides quite wide assistance to injured parties, including consumers, in seeking damages compensation (Bovis and Clarke, 2015, p. 49-71). On the other hand, for the effective protection of consumers as indirect purchasers, a simple transposition of the Directive is insufficient, and some of the Member States should make additional changes to their procedural rules (Butorac Malnar, 2017, p. 72). However, this article does not aim to answer the question concerning amendments of procedural rules in order to facilitate litigation by consumers.

The article aims to analyze the changes that the Damages Directive has made to the passing-on of overcharges in the private enforcement domain. The author does not attempt to cover all Member States' cases related to passing-on. The task is to provide the reader with the analysis of the key problems while implementing the right of an indirect purchaser to sue for damages as well as the use of passing-on as a defence. The tasks of the article are aimed to be achieved by reviewing some relevant cases, the provisions of the Damages Directive, national reports from Central and Eastern European countries (hereinafter, CEE countries), and available relevant studies. It should be emphasized that there is very little relevant literature on the object of the article, since the Damages Directive was only adopted at the end of 2014 and is still being transposed in some Member States. Moreover, there is almost no relevant case law or literature in CEE countries that would provide a basis for a comparative and detailed analysis of the application of passing-on. The present article is likely to be one of the first in Lithuania aimed to cover the issue of passing-on. The subject matter of the research of this article was

2 European Commission, Commission Staff Working Document. Impact Assessment Report. Damages actions for breach of the EU antitrust rules, SWD (2013) 203 final, p. 22. Retrieved from: http://ec.europa.eu/competition/antitrust/actionsdamages/impact_assessment_ en.pdf (22.08.2017). 
analyzed with the help of a logical, systematic analysis and comparative and linguistic research methods.

\section{The concept of passing-on}

The passing-on of overcharges is quite a new and widely discussed topic in European Union law. The roots for the passing-on idea could be found in the Courage ${ }^{3}$ and Manfredi $i^{4}$ decisions of the European Court of Justice. The Court acknowledged therein that any individual is entitled to claim damages for the loss caused. The term 'any individual' is meant to cover both direct and indirect purchasers of the products or services.

The concept of passing-on enshrined in the Directive is focused on indirect purchasers. The Directive defines 'indirect purchaser' as a natural or legal person who acquired, not directly from an infringer, but from a direct purchaser or a subsequent purchaser, products or services that were the object of a competition law infringement, or products or services containing them or derived therefrom.

The basis of the claim of an indirect purchaser derives from the harm suffered after the undertaking directly and negatively affected by the cartel (direct purchaser) increases the prices it charges lower down in the supply line. For example, when producers of milk form a cartel their direct purchasers would be dairy product manufacturers. In such case, indirect purchasers are all buyers (retailers, supermarkets etc.) of dairy products from the milkprocessing companies. The chain of indirect purchasers may be even longer, since the retailers (indirect purchasers) could resell the dairy products further down the line, for example to end-consumers or other business entities (to other retailers).

It is important to note that depending on the situation, passing-on may be used as a basis for the claim (as a 'sword') or as a defence against a claim (as a 'shield') (Strand, 2014, p. 381). It could be used as a basis for the claim (as a 'sword) by an indirect purchaser, where the latter has suffered any harm because of the illegal actions of the cartelists or a dominant company. At the same time, it could be used as a defence (as a 'shield) by the infringer against a damages claim.

Below we would like to use a reference for a scheme of scenarios of passing-on, which was proposed in the Study on the passing-on of overcharges

3 Judgment of 20.09.2001, Courage and Crehan, case C-453/99, ECLI:EU:C:2001:465, para 26.

4 Judgment of 13.06.2006, Manfredi, case C-295/04, ECLI:EU:C:2006:461, para 60. 
that was prepared by external consultants for the Directorate-General for Competition of the European Commission (Durand, Williams, Hitchings, Quintana, Hain-Cole and Loras, 2016).

Table 1. Scenarios of passing-on

\begin{tabular}{|c|c|c|}
\hline \multicolumn{1}{|c|}{ Scenario 1 } & Scenario 2 & Scenario 3 \\
\hline Infringer & Infringer & Infringer \\
\hline Overcharge & Overcharge & Overcharge \\
\hline Claimant = Direct purchaser & Direct purchaser & Direct purchaser \\
\hline Passing-on 1 & Passing-on 1 & Passing-on 1 \\
\hline Indirect Purchaser 1 & Claimant = Indirect purchaser 1 & Indirect Purchaser 1 \\
\hline & Passing-on 2 & Passing-on 2 \\
\hline
\end{tabular}

From the present table, three types of scenarios of passing-on could be distinguished.

In scenario 1, the direct purchaser acts as a claimant. In this case therefore, passing-on may be used as a defence by the infringer. S. Peyer argues that the passing-on defence may have a negative effect on the incentive of direct purchaser to start legal action, since the expected reward from litigation may be reduced because of passing-on. Moreover, it is alleged that legal costs may increase by requiring the quantification of the overcharge (Peyer, 2016, p. 107).

In scenario 2, the Indirect purchaser 1 acts as a claimant. Therefore, passing-on is the basis for the claim of the Indirect purchaser 1. At the same time, passing-on in this case could be used as a defence by the infringer.

In scenario 3, passing-on is used as a basis for the claim of the Indirect purchaser 2 as the end-customer. In this case, the Infringer is not able to use passing-on as a defence, since the end-customer has not passed the overcharge to anyone.

We believe that the above mentioned scenarios provide good assistance to understand how the passing-on might be implemented practically, and what sort of parties could be active in a real litigation. 


\section{The Damages Directive and passing-on of overcharges}

\section{Some provisions in the Damages Directive related to the passing-on of overcharges}

The Directive introduced a separate Chapter governing the passing-on of overcharges and passing-on is, indeed, one of the key topics of the Directive. Bearing in mind the right to full compensation recognized in the jurisprudence of the Court of Justice, the Directive acknowledges in Article 12(1) that all injured parties, including direct and indirect purchasers of the infringer, are entitled to bring a claim. The main novelty of the Directive relates to a detailed description of the right of indirect purchasers to make a claim, since the rights of direct purchasers are more obvious.

There is hope, especially, that the Directive will facilitate claims of indirect purchasers. The Directive establishes a presumption of a passing-on to indirect purchasers, when certain conditions are met. An indirect purchaser should prove the following elements according to Article 14(2) of the Directive: a) that the defendant breached competition law; b) the breach of law caused an overcharge for the direct purchaser; c) the indirect purchaser acquired the goods that were the object of the competition law breach. We welcome the introduction of provisions on indirect purchasers to the Directive. However for the Member States to effectively implement the rights of indirect purchasers, it is also necessary to make amendments to their procedural rules concerning collective redress.

Article 14 of the Directive also provides that the presumption will not apply when the infringer can prove that the overcharge was not, or was not entirely, passed on to the indirect purchaser. It is claimed that finding that a passing-on of an overcharge took place will substantially depend on the question whether the overcharge could have affected a large proportion of the final product's price. At the same time, if the allegedly overcharged product (element) was not of key importance for the final price, then this increases the chances that the passing-on of an overcharge will not be recognized. For example, the Appeal Court of Madrid found in one of its cases that since sugar constituted around $75 \%$ of the total cost of some candy products, the passing-on of overcharges was deemed to be persuasive. ${ }^{5}$ On the other hand, if the overcharged product would equal to only $1 \%-5 \%$ of the overall cost, the passing-on might not be sufficiently proven.

5 Judgment of Appeals Court of Madrid of 03.10.2011, Nestlé \& ors v. Ebro Puleva, case No. 370/2011. 
The number of the affected parties is also important for the evaluation of passing-on. In the Arkopharma case, it was established that a cartel involved approximately $80 \%$ of the producers of vitamins. Therefore, it seems persuasive that direct purchasers will experience an overcharge. If only a few companies are affected, the court may conclude that there was no passing-on. ${ }^{6}$

Article 16 of the Directive provides that the Commission shall issue guidelines for national courts on how to estimate the share of the overcharge that was passed on to the indirect purchaser. However, although 2 years since the adoption of the Directive have passed, the promised guidelines have still not been prepared. Currently, we can refer only to the above mentioned Study on the passing-on of overcharges (Durand, Williams, Hitchings, Quintana, Hain-Cole and Loras, 2016).

\section{Causation}

The Damages Directive hardly addresses the issue of causation, although it is one of the key questions in private damage claims. The national reports from Estonia and Croatia concerning the implementation of the Damages Directive have also emphasized the importance of causation for the establishment of passing-on (Pärn-Lee, 2017, p. 115; Butoca Malnar, 2017, p. 72.). Paragraph 11 of the Preamble to the Directive provides that all national rules governing the exercise of the right to compensation for harm, including the notion of a causal relationship between the infringement and the harm, must observe the principles of effectiveness and equivalence. It also states that national rules should not be formulated or applied in a way that makes it excessively difficult or practically impossible to exercise the right to compensation.

The principles of effectiveness and equivalence are, indeed, of key importance while evaluating causation. In the Kone case, ${ }^{7}$ the Court of Justice dealt with the question whether Article 101 TFEU has to be interpreted as meaning that any person may claim damages from the members of a cartel for the loss caused by a person not party to the cartel who, benefiting from the protection of the increased market prices, raises his/her own prices more than s/he would have done without the cartel ('umbrella pricing'). The Court of Justice held that on the basis of the principle of effectiveness, any individual could claim compensation for harm suffered regardless of the existence

\footnotetext{
${ }^{6}$ Judgment of Commercial Court of Nanterre of 11.05.2006, Arkopharma v. Group Hoffmann la Roche, case No. 2004F022643.

7 Judgment of 05.06.2014, Kone AG, Otis GmbH, Schindler Aufzüge und Fahrtreppen GmbH, Schindler Liegenschaftsverwaltung GmbH, Thyssen Krupp Aufzüge GmbH v. ÖBB-Infrastruktur $A G$, case C-557/12, ECLI:EU:C:2014:1317.
} 
of a direct causal link. Victims of 'umbrella pricing' should be able to get compensation for the loss caused by the cartel, even if it had no contractual links with them, where it is established that the cartel could have had the effect of umbrella pricing benefiting third parties acting independently, and that those specific circumstances could not be ignored by the members of the cartel.

The ruling in the Kone case has far-reaching consequences for the understanding of the concept of a causal link, which is also important to the calculation of the passing-on of overcharges.

First, it is obvious that the Court of Justice does not require a direct causal link and that indirect causation may be sufficient. This also automatically expands the circle of potential plaintiffs and includes also indirect purchasers and consumers.

Second, from the rationale of the Court of Justice on 'umbrella pricing', we presume that the Court may be encouraged to refer to the 'foreseeability' of the occurrence of the damage as a one of the conditions for proving a causal link. It seems that the Court already decided to refer to the principle of the 'foreseeability' of the damage, although it is still not formulated black on white.

Third, the development of the notion of causation in relation to private enforcement claims and passing-on of overcharges may have a much wider influence on the development of causation in regular civil law litigation of the Member States. We may even presume that the development of private enforcement principles established in the Damages Directive (including passing-on, causation, etc.) could facilitate the harmonization of the tort law all around the European Union.

It should be noted that there are currently a couple of interesting civil litigations underway in Lithuania against audit companies who made audit reports for banks that later went bankrupt. Some of the claimants are depositors of the bankrupt banks who had put their money into these specific banks relying inter alia on the audit reports prepared by some reputable Big 4 audit companies. The claimants allege inter alia that the auditors should have foreseen that their audit report will be read by third parties, including depositors. Therefore, if the third parties (depositors) suffer damages because of the content of the audit reports then the auditors should be liable. These disputes are currently only before first instance courts in Lithuania and will probably reach the Supreme Court. There is, therefore, quite a long time to wait for the final decisions. ${ }^{8}$

8 The author as an attorney represents depositors in a few dozen million claims against one of the Big 4 of the audit company. One of the key issues in this case is proving the causation. 
The issue of causation will probably be comprehensively analyzed, especially in cases when indirect purchasers will file a claim for damages. Causation may be tricky when an indirect purchaser claims that s/he suffered an 'overcharge harm' because of passing-on. In most cases, the issue of causation will be decided mainly by national courts based on national procedural rules. However, if the recognition of causation is left completely to national courts, they could find that the loss is too remote. Therefore, there was a need for harmonization through the directive, since otherwise such rights may not be implemented at all.

The recognition of the right to full compensation enshrined in the Directive is of key importance, since it also means that any injured person may claim damages. Moreover, the principles of effectiveness and equivalence require that the exercise of all the rights stemming from EU law is protected. Practically, it also means that national substantive and procedural rules may not be applicable, if they preclude the effective exercise of EU rights. We believe that arguing in the courts will be aplenty in the future that certain national regulations (including procedural rules) preclude effective private enforcement litigations.

Another important factor in dealing with causation is economics. Economists and economic theories are meant to be used to a high extent in cases concerning passing-on (Smuda, 2014, p. 63-86). The courts will need economists to evaluate whether specific evidence satisfactorily proves the reality of passing-on (Durand, Williams, Hitchings, Quintana, Hain-Cole and Loras, 2016). Professors Lianos, Davis and Nebia also share the opinion that causation is one of the most difficult topics that need to be assisted by a comprehensive use of economic methods (Lianos, Davis and Nebbia, 2015, p. 74). We would definitely need economic assistance in order to calculate the amount of the overcharge in the above mentioned example of the alleged passing-on by dairy products manufacturers to the cheese shop. Moreover, without economic methods it would not be possible to determine what persons and at which level of the supply chain could have been negatively affected by the cartel.

\section{Impact of the overcharge}

As previously mentioned, the evaluation of the exact impact of an overcharge is quite complex and should be properly done with the assistance of economists. Economists distinguish a couple of elements of an overcharge.

The first element is the overcharge (cost) effect. The increase in prices by members of the cartel causes damage to direct purchasers. For example, 
if milk producers conclude a cartel then a dairy product manufacturer who buys milk in order to produce cheese will face increased costs of the raw material (milk). To calculate the exact level of the overcharge we should consider the level of the output and the amount of the unit cost increase. The Damages Directive does not cover the issue of the quantification of harm, but the Practical guide quantifying harm in actions for damages (hereinafter, Practical guide) lends a helping hand in this context. ${ }^{9}$ However, in some cases, the Practical guide may not offer enough assistance and a consultation from a national competition authority might be needed. Article 17 of the Damages Directive provides that national court may request a national competition authority to assist the court with respect to the determination of the quantum of damages.

The second element is the passing-on of the overcharge. The direct purchaser will usually try to pass on at least part of the overcharge to its customers (indirect purchasers). The amount of the passing-on of the overcharge might be calculated by multiplying the level of the output with the downstream price increase. This element indicates the additional revenue received by the direct purchaser.

The third element that needs to be considered is the volume effect (lost business). In most cases after the direct purchaser increases its prices, the customers will start buying fewer products. This may mean a decrease in sales and less money for the direct purchaser. Therefore, this needs to be considered while calculating damages suffered by the direct purchaser. Moreover, to our knowledge, there has only been one instance so far of a Member State's court assessing the volume effect in a case named Cheminova. ${ }^{10}$ Therein, Cheminova (producer of pesticides) filed a claim for damages against Akzo Nobel for its participation in a cartel. It was concluded that Cheminova had passed on around $50 \%$ of the overcharges. It was also found that Cheminova, because of the passing-on, suffered losses in the amount of $20 \%$ of the overcharges. Finally, the Court considered the volume effect and increased the amount of the compensation for Cheminova.

To calculate the damage experienced by a direct purchaser, we should calculate the overcharge effect, then take away the passing-on of the overcharge, and finally add the volume effect. This is the way for the calculation of damages

${ }^{9}$ European Commission, Commission Staff Working Document. Practical guide quantifying harm in actions for damages based on breaches of Article 101 or 102 of the Treaty on the Functioning of the European Union, SWD (2013) 205. Retrieved from: http://ec.europa.eu/ competition/antitrust/actionsdamages/quantification_guide_en.pdf (22.08.2017).

10 Judgment of Maritime and Commercial Court of 15.01 .2015 , Cheminova A/S v. Akzo Nobel Functional Chemicals BV and Akzo Nobel Base Chemicals AB, case No. U-4-07. 
proposed in the Study on the passing-on of overcharges (Durand, Williams, Hitchings, Quintana, Hain-Cole and Loras, 2016, p. 12).

On the other hand, the amount of the damage experienced by the endcustomer equals the second element, that is, the downstream overcharge. There is also a lost consumption effect (or a deadweight loss), which is used by some economists in order to calculate the comprehensive damage to consumers. Deadweight loss is sometimes described as 'the loss of satisfaction of end customers, which would result from being denied the enjoyment of some consumption as a result of inflated prices' (Durand, Williams, Hitchings, Quintana, Hain-Cole and Loras, 2016, p. 13). It should be added that currently Member States' courts do not consider deadweight loss as recoverable by end-consumers.

\section{Member States' regulation on passing-on}

The rules on passing-on of overcharges are quite new to the legal acts of many Member States. Moreover, in most Member States the legislator chose a very simple solution and quite literally transposed the provisions of the Directive. Therefore, in most cases there is not a lot left for interpretation. The national reports are quite short-spoken on passing-on. At the same time, for example the national report from the Czech Republic states that Article 15 of the Directive, concerning actions for damages by claimants from different levels in the supply chain, was not transposed into Czech law, since such rules were already applicable in Czech law. The Czech legislator also chose not to transpose the Directive's provisions concerning full compensation and the prohibition of overcompensation concerning passing-on, since it was chosen to rely only on the general principles (Petr, 2017, p. 95).

It is also interesting to note that Estonian law does not use the concept of the passing-on defence that is defined in Article 13 of the Directive. On the other hand, it is stated that this concept is already practically applicable according to Estonian law, since the defendant is entitled to rebut the damages claims of the applicant (Pärn-Lee, 2017, p. 115).

The national reports concerning the implementation of the Damages Directive in Bulgaria, Croatia, Czech Republic, Estonia, Hungary, Latvia, Lithuania, Poland, Romania Slovakia and Slovenia provide that there are no decisions yet of the national courts elaborating on the concept of passing-on (Piszcz, 2017). We believe that there are several reasons for the lack of corresponding practice in Lithuania and other Baltic states.

First, there are certain barriers that in general prevent the increase of antitrust damage claims (Moisejevas, 2015). Key among those barriers are: the 
complexity of competition cases; lack of clear-cut jurisprudence of Lithuanian courts; prolonged litigation in antitrust damage claims; high legal standard for proving the causal relationship between the anti-competitive action and the damages incurred; and difficulties related to the calculation of the quantum of antitrust damage. Slow development of private enforcement in the EU is recognized by some scholars as a reason for the lack of case law on passing-on (Parlak, 2010, p. 44; Petrucci, 2008, p. 41).

Second, after analyzing private enforcement cases brought forward in Poland, Latvia, Estonia, Slovakia and other CEE countries, it came as no surprise that most private enforcement cases originated from an abuse of dominance (Brkan and Bratina, 2013, p. 75-106; Jurkowska-Gomułka, 2013, p. 107-128; Piszcz, 2012, p. 55-77; Sein, 2013, p. 129-140). Moreover, in most cases antitrust damage claims in CEE countries are submitted as follow-on actions. On the other hand, it is fair to presume that most of the cases related to the passing-on of overcharges relate to cartels. Such statement is also supported by existing court practice.

\section{Conclusions}

The concept of the passing-on of overcharges is one of the most complicated in the Damages Directive. It is highly probable that in most cases the passing-on will need to be evaluated with the assistance of economists. Passing-on may be used as basis for a claim (as a 'sword') or as a defence (as a 'shield'). It could be used as a basis for a claim by an indirect purchaser where the latter has suffered any harm because of the illegal actions of cartelists or a dominant company. At the same time, it could be used as a defence by the infringer against a damages claim.

Causal link is very important for the assessment of passing-on. The Court of Justice recognizes indirect causation as sufficient. This also automatically expands the circle of potential plaintiffs and includes also indirect purchasers and consumers. From the rationale of the Court of Justice on the issue of 'umbrella pricing', we presume that the Court may be encouraged to refer to the 'foreseeability' of the occurrence of the damage as one of the conditions for proving the causal link. Moreover, the development of the notion of causation in relation to private enforcement claims and the passing-on of overcharges may exercise a much wider influence on the development of causation in regular civil law litigation of the Member States. We even make a guess that the development of private enforcement principles established in the Damages Directive (including passing-on, causation, etc.) could facilitate the harmonization of tort laws all around the European Union. 


\section{Literature}

Bovis, C.H. and Clarke, C.M. (2015). Private Enforcement of EU Competition Law. Liverpool Law Review, 36, 49-71.

Brkan, M. and Bratina, T. (2013). Private Enforcement of Competition Law in Slovenia: A New Field to Be Developed by Slovenian Courts. Yearbook of Antitrust and Regulatory Studies, 6(8), 75-106.

Butorac Malnar, V. (2017). Croatia. In: A. Piszcz (ed.), Implementation of the EU Damages Directive in Central and Eastern European Countries (55-84). Warsaw: University of Warsaw, Faculty of Management Press.

Durand, B., Williams, I., Hitchings, P., Quintana, Hain-Cole, J. and Luis, L. (2016). Study on the Passing-On of Overcharges. Final report. doi: 10.2763/590101. Retrieved from: https://publications.europa.eu/en/publication-detail/-/publication/a18be06b-fa5d-11e68a35-01aa75ed71a1/language-en/format-PDF (22.08.2017).

Jurkowska-Gomułka, A. (2013). Private Enforcement of Competition Law in Polish Courts: The Story of an (Almost) Lost Hope for Development. Yearbook of Antitrust and Regulatory Studies, 6(8), 107-128.

Lianos, I., Davis, P. and Nebbia, P. (2015). Damages Claims for the Infringement of EU Competition Law. Oxford: Oxford University Press.

Moisejevas, R. (2015). Development of Private Enforcement of Competition Law in Lithuania. Yearbook of Antitrust and Regulatory Studies, 8(11), 35-52.

Parlak, S. (2010). Passing-on defence and indirect purchaser standing: should the passing-on defence be rejected now the indirect purchaser has standing after Manfredi and the White paper of the European Commission? World Competition, 33(1), 31-53.

Pärn-Lee, E. (2017). Estonia. In: A. Piszcz (ed.), Implementation of the EU Damages Directive in Central and Eastern European Countries (109-126). Warsaw: University of Warsaw, Faculty of Management Press.

Petr, M. (2017). Czech Republic. In: A. Piszcz (ed.), Implementation of the EU Damages Directive in Central and Eastern European Countries (85-108). Warsaw: University of Warsaw, Faculty of Management Press.

Petrucci, C. (2008). The issues of the passing-on defence and indirect purchaser standing in European competition law. European Competiton Law Review, 29(1), 33-42.

Peyer, S. (2016). Compensation and the Damages Directive. European Competition Journal, $12(1), 87-112$.

Piszcz, A. (2012). Still-unpopular Sanctions: Developments in Private Antitrust Enforcement in Poland After the 2008 White Paper. Yearbook of Antitrust and Regulatory Studies, 5(7), $55-77$.

Piszcz, A. (ed.). (2017). Implementation of the EU Damages Directive in Central and Eastern European Countries. Warsaw: University of Warsaw, Faculty of Management Press.

Sein, K. (2013). Private Enforcement of Competition Law - the Case of Estonia. Yearbook of Antitrust and Regulatory Studies, 6(8), 129-140, doi:10.2139/ssrn.2736227.

Smuda, F. (2014). Cartel overcharges and the deterrent effect of EU competition law. Journal of Competition Law and Economics, 10(1), 63-86.

Strand, M. (2014). Indirect purchasers, passing-on and the new directive on competition law damages. European Competition Journal, 10(2), 361-386. 